\title{
DIGITAL STORY: AN EFFECTIVE MEDIA TO TEACH LISTENING FROM THE PERSPECTIVE OF STUDENTS' SCHEMATA
}

\author{
Dwi Rosita Sari \\ Department of English Teaching \\ IKIP PGRI Madiun \\ rositasari_dwi@yahoo.com
}

\begin{abstract}
The objectives of this research are to identify the effectiveness of Digital Story Media in teaching listening, and whether there is an interaction between the media and students' schemata. This experimental study was conducted at a university in Madiun, East Java.The population was the second semester students of this university in the academic year of 2012/2013. Cluster random sampling was used to select 132 students for obtaining two classes of sample and they are randomly classified into two groups: experimental and control group. The instruments of this research were listening test and students' schemata questionnaire. The data were analyzed using Liliefors and Bartlete tests to investigate the normality and the homogeneity of the data. After that, ANOVA and TUKEY tests were used to test the hypotheses. The research findings show that: (1) Digital Story Media is more effective than Animation Video in teaching listening; (2) the students having high schemata have better listening skill than the students having low schemata; and (3) there is an interaction between teaching media and students' schematain teaching listening. That Digital Story Media is effective to teach listening, however teachers are suggested to improve the students' schemata because it affects students listening achievements.
\end{abstract}

Key words: Digital Story Media, animation video, students' schemata, listening, experimental study.

\section{INTRODUCTION}

In learning English, there are four skills which are important to learn: listening, speaking, reading, and writing. All those skills are supposed by some components such as vocabulary, grammar, pronunciation, etc. Listening is one skill that should be mastered by the students nearly all level of school. In listening process, some sentences or messages are transferred from the speaker to the listener orally. Floyd (in Brownell, 1997: 45) states that listening is a process that includes hearing, attending to, evaluating, and responding to spoken language. This means that listening consists of some activities, such as : 1) hearing to spoken language; 2) attending to spoken language; 3) evaluation of the spoken language; and 4) responding to spoken language.

Krashen (in Underwood, 1997: 102) argues that listening is a valuable source of what he calls "comprehensible input'. Comprehensible input means a flow of language which contains elements already known plus some which has yet to be mastered.

Underwood (1997: 1) states that listening is the activity of paying 
attention to and trying to get meaning from something we hear. She explains that to listen succesfully to spoken language, a listener needs to be able to work out what speakers mean when they use particular words in particular ways on particular occasions, and not simply to understand the words themselves. To understand the massage from spoken language, it is not enough to just understand the words themselves, intead the incoming sound need to be processed involving any available cues like background noises, the speakers, the setting, etc. to construct meaning.

Brown (2004: 138) argues that listening is a process that is done by test-takers to identify the gist, main idea, purpose, supporting points, and/or conclusion to show full comprehension. It means there are five indicators of listening: (1) identifying the gist; (2) identifying main idea; (3) identifying purpose; (4) identifying supporting points; (5) identifying conclusion to show full comprehension.

Smith and Fitt (1992: 247) state when use at the reference desk, active listening is a way to discover the patron's real information needs, at times when request at assisstance are vague or unclear. It means in active listening the listener involves the process of getting the reference in order to comprehend the whole meaning of the text.
Because of the condition, learners should understand well between the different language system of the Second language and the foreign language. This understanding helps them to get much in listening process when listening become a habit, it is easier for the listener to understand and comprehend the native speaker's language.

One of difficult subjects in teaching and learning process is listening. Students have low comprehension of target language, as it can be seen in the academic score. Most of the students have low marks in the listening subject. Low academic score is the result of low accesses of teaching learning process. Students cannot develop their ways to discover the understanding of native language.

Another reason which makes the students get low academic score in listening is low activation of schemata. Schemata are background knowledge or prior knowledge of the students. According to Barlett in Flowerdew and Miller (2005: 26) a schema consists of an active organization of past experiences. It covers knowledge about certain properties of objects, events, and actions which typically belong together. The basic idea is that human knowledge is organized and stored in memory according to re-occuring events. The knowledge in our heads is internally organized into interrelated patterns that are constructed from an 
individual's past experience of a given environment (Bartlett in Suhsun Chang, (1995:200). Schemata have an important role in listening comprehension process. Schemata or prior knowledge will construct individuals understanding of something with the past experience. That, the main pattern will interrelate to each other. This condition creates an easier way to catch the massage on listening process. Inshort, listening is an active process in which the activities are hearing, paying attention in order to construct meaning and responding to the spoken language by relating the background knowledge (schemata) and the message to identify the gist, purpose, supporting points, reference, inference and conclusion to show full comprehension.

The next reason the students have low academic score is the lack of variation of media in listening subject. Usually, listening teacher uses cassettes recorder only and sometimes the media are unrelated to the materials. Because of that, the teacher should increase the using of variations of media.

Later, media are various. In a digital era today, many kinds of media are created. The media can be in the shape of multimedia, presentive or interactive. In listening process, contextual media are required. The media should be relevant with the context and schemata of the students.
One of the media which can be useful in listening process is Digital Story Media. Digital Story Media is used to help the learners to create an easier way to study listening comprehension to the target language. Digital Story Mediais the combination media between the art of telling story with variety of digital multimedia, such as images, audio, and video. The process of telling the stories called Digital Story Mediatelling.Robin (2006: 01) states Digital Story Mediatelling is the process of combining the arts of telling stories with variety of digital multimedia, such as images, audio, and video. At its core, Digital Story Mediatelling allows computer users to become creative storytellers through the traditional processes of selecting a topic, conducting some research, writing a script, and developing an schemataing story. This material is then combined with various types of multimedia, including computer-based graphics, recorded audio, computer-generated text, video clips, and music so that it can be played on a computer, uploaded on a web site, or burned on a DVD.

Digital Story Media has seven elements. The seven elements can be seen in the table 1.

Table 1. The Seven Elements of Digital Story Media

\begin{tabular}{|c|c|c|}
\hline 1. & $\begin{array}{l}\text { Point of } \\
\text { view }\end{array}$ & $\begin{array}{l}\text { What is the main point of the } \\
\text { story and what is the } \\
\text { perspective of the author }\end{array}$ \\
\hline 2. & $\begin{array}{l}\text { A dramatic } \\
\text { question }\end{array}$ & $\begin{array}{l}\text { A key question that keeps the } \\
\text { viewer's attention and will be } \\
\text { answered by the end of the } \\
\text { story. }\end{array}$ \\
\hline
\end{tabular}




\begin{tabular}{|c|c|c|}
\hline 3. & $\begin{array}{l}\text { Emotional } \\
\text { content }\end{array}$ & $\begin{array}{l}\text { Serious issues that come alive } \\
\text { in a personal and powerful way } \\
\text { and connects the story to the } \\
\text { audience. }\end{array}$ \\
\hline 4. & $\begin{array}{l}\text { The gift of } \\
\text { your voice }\end{array}$ & $\begin{array}{l}\text { A way to personalize the story } \\
\text { to help the audience } \\
\text { understand the context. }\end{array}$ \\
\hline 5. & $\begin{array}{l}\text { The power } \\
\text { of the } \\
\text { soundtrack }\end{array}$ & $\begin{array}{l}\text { Music or other sounds that } \\
\text { support and embellish the } \\
\text { storyline. }\end{array}$ \\
\hline 6. & Economy & $\begin{array}{l}\text { Using just enough content to } \\
\text { tell the story without } \\
\text { overloading the viewer. }\end{array}$ \\
\hline 7. & Pacing & $\begin{array}{l}\text { The rhythm of the story and } \\
\text { how slowly or quickly it } \\
\text { progresses. }\end{array}$ \\
\hline
\end{tabular}

Formerly, teacher uses Animation Video to teach listening. An Animation Video is the part of authentic material which is used in listening activity. Animation Video is the part of authentic material which is used in listening activity. Animation comes from "anima" (Latin) means soul, life, or spirit. Animation is an object of picture which imitates the living things. Animation is a combination of an audio (sounds) and visual (pictures). So, animation is called as an audio visual media. Tversky and Morrison (2002: 250) state animation is an attractive graphic devices. Graphic means the images are visually symbolic and representational of something. Moreover, animation is an attractive images. Animation Video uses certain pictures, graphs, sounds, text. Later, Digital Story Media is more effective than Animation Video. Digital Story Media is completed by the context.

\section{RESEARCH METHODOLOGY}

The research was an experimental study conducted at one university in Madiun, East Java from January to June 2013.
The population was the second semester students which consisted of 4 classes with the total of 132 students. The samples were two classes namely experimental class which was taught using Digital Story Media and control class which was taught using Animation Video. To find out the sample, a cluster random sampling technique was implemented. Each class was divided into two groups of which each consisted of students having high schemata and those having low schemata. To gain the data, two instruments were used namely listening test to find out the score of students' listening skills and schemata questionnaire to find out the score of students' schemata. The two instruments were, firstly, tried out to measure the validity and reliability. The data were analyzed by using Multifactor Analysis of variance ANOVA 2x2 and Tukey HSD test. Before conducting the ANOVA test, pre-requisite test namely normality and homogeneity test were conducted.

\section{RESEARCH FINDINGS AND DISCUSSIONS}

To find out whether the Ho (null hypothesis) is rejected or accepted. Multifactor analysis of variance (ANOVA) is used to test the hypothesis. The summary of ANOVA test can be seen in the table 2. 
Table 2.The Summary of a 2x2

Multifactor of Variance

\begin{tabular}{lcccccc}
\hline $\begin{array}{l}\text { Source of } \\
\text { Variance }\end{array}$ & SS & df & MS & Fo & $\begin{array}{c}\mathrm{Ft}_{(0,0} \\
5)\end{array}$ & $\begin{array}{c}\mathrm{Ft}_{(0 \cdot 0} \\
1)\end{array}$ \\
\hline $\begin{array}{l}\text { Between } \\
\text { columns } \\
\text { (media) }\end{array}$ & 317.29 & 1 & 317.29 & 7.19 & 4.00 & 7.08 \\
$\begin{array}{l}\text { Between } \\
\text { rows } \\
\text { (schemata) }\end{array}$ & 363.38 & 1 & 363.38 & 8.23 & & \\
$\begin{array}{l}\text { Columns by } \\
\text { rows } \\
\text { (interaction) }\end{array}$ & 1832.91 & 1 & 1832.91 & 41.52 & & \\
$\begin{array}{l}\text { Between } \\
\text { groups }\end{array}$ & 2513.57 & 3 & 837.86 & 18.98 & & \\
$\begin{array}{l}\text { Within } \\
\text { groups }\end{array}$ & 2648.83 & 60 & 44.15 & & & \\
Total & 5162.40 & 63 & & & & \\
\hline
\end{tabular}

Table 3.Table of the Mean Scores of the Cells

\begin{tabular}{|c|c|c|c|}
\hline $\mathrm{S}_{\text {SCHEMATA }}^{\text {MEDIA }}$ & $\begin{array}{c}A_{\dot{1}} \\
\text { (DS) }\end{array}$ & $\underset{(\mathrm{AV})}{\mathrm{A}_{\mathrm{B}}}$ & \\
\hline $\begin{array}{c}\mathrm{B}_{1} \\
\text { (High) }\end{array}$ & 76.25 & 61.09 & 68.67 \\
\hline \multirow[t]{2}{*}{$\begin{array}{c}\mathrm{B} \\
(\mathrm{Low})\end{array}$} & 60.78 & 67.03 & 63.91 \\
\hline & 68.52 & 64.06 & \\
\hline
\end{tabular}

The table 2 and 3 show that:

1. Because $F_{0}$ between columns (7.19) is higher than $F_{t}$ at the level of significance $\alpha=0.05$ (4.00), the difference between columns is significant. Therefore, the null hypothesis $\left(\mathrm{H}_{0}\right)$ stating that there is no significant difference in listening skill between the students who are taught by using Digital Story Media and students who are taught by using Animation Video is rejected. It can be concluded that the teaching media differ significantly from one another in their effect on listening skill.

2. Because $F_{o}$ between rows (8.23) is higher than $F_{t}$ at the level of significance $\alpha=0.05$ (4.00), the difference between rows is significant. Therefore, the null hypothesis $\left(\mathrm{H}_{\mathrm{o}}\right)$ stating that there is no significant difference in listening skill between the students who have low schemata and students who have high schemata is rejected. It can be concluded that students having high schemata and those having low schemata are significantly different in their listening skill.

3. Because $F_{0}$ interaction (41.52) is higher than $F_{t}$ at the level of significance $\alpha=0.05$ (4.00), there is an interaction effect between teaching media and schemata toward students' listening skill. Therefore, the null hypothesis $\left(\mathrm{H}_{\mathrm{o}}\right)$ stating that there is no interaction between teaching media and students' schemata in listening skill is rejected. It means that the effect of teaching media depends on the degree of schemata.

Furthermore, to find out whether the mean difference between the cells is significant or not, Tukey's HSD test was used. The summary of Tukey test can be seen in the table 4 .

Table 4. The Summary of Tukey Test

\begin{tabular}{ccccc}
\hline $\begin{array}{c}\text { Between } \\
\text { groups }\end{array}$ & qo & qt(0.05) & Meaning & Category \\
\hline A1 - A2 & 3.79 & 2.86 & qo $>$ qt & Significant \\
\hline B1 - B2 & 26.01 & 2.86 & qo $>$ qt & Significant \\
\hline $\begin{array}{c}\text { A1B1 - } \\
\text { A2B1 }\end{array}$ & 9.12 & 3 & qo $>$ qt & Significant \\
\hline $\begin{array}{c}\text { A1B2 - } \\
\text { A2B2 }\end{array}$ & 3.76 & 3 & qo $<\mathrm{qt}$ & Significant \\
\hline
\end{tabular}


The finding of $q$ is found by dividing the difference between the means by the square root of the ratio of the within group variation and the sample size: (1) because $\mathrm{q}_{\mathrm{o}}$ between columns $\left(A_{1}-A_{2}\right)$ (3.79) is higher than $q_{t}$ at the level of significance $\alpha=0.05$ (2.86), applying Digital Story Media differs significantly from picture to teach listening. Because the mean of $\mathrm{A}_{1}$ (68.52) is higher than that of $A_{2}$ (64.06), it can be concluded that Digital Story Media is more effective than Animation Video to teach listening; (2) because $\mathrm{q}_{0}$ between rows $\left(\mathrm{B}_{1}-\mathrm{B}_{2}\right)$ (26.01) is higher than qt at the level of significance $\alpha=$ 0.05 (2.86), it can be concluded that the students who have high and those who have low schemata are significantly different in their listening ability. Because the mean of $B_{1}$ (64.06) is higher than $\mathrm{B}_{2}$ (33.52), it can be concluded that the students who have high schemata have better listening ability than those have low schemata; (3) because $\mathrm{q}_{\mathrm{o}}$ between cells $A_{1} B_{1}$ and $A_{2} B_{1}$ (9.12) is higher than $\mathrm{q}_{\mathrm{t}}$ at the level of significance $\alpha=0.05$ (3.00), using Digital Story Media media differs significantly from Animation Video media to teach listening for the students who have high schemata. Because the mean of $A_{1} B_{1}$ (75.78) is higher than $A_{2} B_{1}$ (60.63), it can be concluded that Digital Story Media is more effective than Animation Video for teaching listening to the students having high schemata; (4) because $q_{o}$ between cells $A_{1} B_{2}$ and $A_{2} B_{2}(3,76)$ is higher than $q_{t}$ at the level of significance $\alpha=0.05$ (3.00), using Digital Story Media differs significantly from Animation Video to teach listening for the students who have low schemata. Because the mean of $A_{2} B_{2}$ (67.03), is higher than $A_{1} B_{2}$ (60.52), it can be concluded that Animation Video is more effective than Digital Story Media in teaching listening for the students having low schemata.

\section{DISCUSSION}

Digital Story Media is more effective than Animation Video to teach listening. Table 2 and table 4 show that Digital Story Media differs significantly from Animation Video. The mean score of the students who are taught by using Digital Story Media is higher than those who are taught by using Animation Video. The findings of this study in line with what Rubin (1994: 102) states that the listening comprehension of high-beginning students who watch video improved significantly over the students who received no video support their listening training. It means that video can enhance listening comprehension.

Furthermore, Herron et al (1991: 64) states that students listening comprehension improved more after exposure to a video-based curriculum. This research explains that the using of use of can improve the students listening comprehension and listening 
skills. Video covers the multimedia which involves visual support of text. Mueller (1980: 335) shows that the helpfulness of the visual clues is inversely related to proficiency levels. Robin (2006: 01) adds the understanding that the video which has multimedia forms, such as images, audio, and video which combines with the art of telling story is called as Digital Story Media.

Moreover, the findings of this research have little bit different with the previous research. The main different point is the previous researches focus on the use of video in general. But, this research focuses on the Digital Story Media video. The researcher found that not all the video are effective to teach listening, such as Animation Video. Digital Story Media is more effective to teach listening because Digital Story Media uses a real-life articulatory phonetics of human's speech organs. In contrary, Animation Video uses unreallife articulatory phonetics of human's speech organs. The students will be difficult to catch the articulatory phonetics of the words. Based on the explanation above, the findings of the research reveal that Digital Story Media is more effective than Animation Video to teach listening skills.

The students who have high schemata have better listening skill than those who have low schemata. Table 2 and table 4 show that stdents having high schemata differ significantly from those having low schemata in their listening skill. The mean score of students having high schemata is higher than those having low schemata, the finding of this study in line with what Long (1985:80). He considers whether listeners comprehend better when they prossess schemata relevant to the listening topic. The background knowledge is closely related to the listening comprehension.

Furthermore, Schmidt-Rinehart (1992: 105) state that comprehension was assessed through a recall protocol. Results of the study showed that both topics familiarity and course levels affect measures of listening comprehension. All subjects recalled significantly more information from the familiar topicand the improvement in comprehension score ascended with the quarter level. The use of familiar topic with helpfulness for the students to understand and comprehend the listening.

Moreover, Rubin (2011:209) states that current views on listening comprehension agree that background knowledge or prior knowledge (also called declarative knowledge) affect listening comprehension. It means schemata have big role in listening activities. Second caracteristics of effective and good listening is that listening should be proceded by 
schemata - builds or background knowledge.

In all three previous studies, schemata was shown to improve listening comprehension. That, the students should have high schemata. The characteristics of the students having high and low schemata was stated by Anderson (1977: 418-419). The students have good self preparation, good self organization, and good incorporation in all different kinds of knowledge. Students with high schemata can predict the input of listening well. Meanwhile, the students having low schemata have the opposite characteristics. They have unwell organization of the knowledge, unwell recognition and incorporation of some knowledge. They can not predict the input of knowledge well.

Those three previous researches have little bit different with the findings of this research. This research uses a sample of English as a second language students. The students have high schemata in first language terms. So, they have limited vocabulary to express their background knowledge which relevant with the topic of listening. While, the three previous research uses sample of English as a first language students. The students having high schemata in first language terms. They have unlimited vocabulary to express and relate their background knowledge to the relevant topic of listening.
However, based on the data of the research findings, the students of English as a second language students having high schemata have better listening skills than those having low schemata.

There is an interaction effect between teaching media and students' schemata on the students' listening skill. Table 2 and table 4 show that Digital Story Media media differs significantly from Animation Video media to teach listening for the students who have high schemata and those who have low schemata. Digital Story Media is more effective than Animation Video in teaching listeing for students who have high schemata and Animation Video is more effective than Digital Story Media in teaching listening for the students who have low schemata.

The findings of the research support by some experts. The teaching media which is used by the teacher in the class gives a big influence for the success of the teaching and learning process. There are many advantages of using technology in education. Roblyer (2003: 164) states that some advantages of using technology as a media for the instructional processes: (1) gaining learners attention; (2) engaging the learners through production work; (3) increasing perceptions of control. It means that the using of technology as media in teaching and learning process 
is important. Meanwhile, schemata are another important factor for influencing achievement in school. The students who have high schemata usually achieve higher score because they can relate the relevant background knowledge with the materials given by the teacher.

The using of Digital Story Media will be more effective when the students have high schemata about the materials. The Digital Story Media is provides context which relevant to the students schemata and the activation of schemata in the brain will be stronger. As the result students will be easier to predict the new information contextually. Because students who have high schemata have some characteristics. Anderson (1977: 418419) states the characteristics of the students who have high schemata are: a) students' schemata are always organized meaningfully; b) students' schemata may be reorganized when incoming data reveals; c) students use the mental representations during perception and comprehension; d) students' can incorporate all the different kinds of knowledge; e) students' schemata can predict the input well. They can catch the messages which convey by the speaker easily. Last, the listener can respond the speaker messages correctly.

On the other hand, Animation Video is suitable for the students who have low schemata because it is not completed by moving images which convey the textual and contextual information. Students who have low schemata have some characteristics. Anderson (1977: 418-419) states the students who have low schemata are: a) students' schemata are unorganized well in the memory; b) students' schemata cannot reorganized well; c) students' are not encourage the mental representation; d) students cannot incorporate the different knowledge; e) students' schemata are irrelevant with the input of the materials. In short, there is an interaction between Digital Story Media with the students who have high schemata and there is also an interaction between Animation Video with the students who have low schemata.

\section{CONCLUSION}

The result of the research implies that students' schemata give an effect on students' listening skill. Students having high schemata have better listening skill than those having low schemata. Students having high schemata to be able to predict and relate their background knowledge to the topic of listening, since they have characteristics such as: good self preparation, good self organization, and good incorporation in all different kinds of knowledge. Digital Story Media is a multimedia which helps students to understand and 
comprehend the topic of listening by analyzing the contextual situation of the story and relate it to their schemata. Since it is very effective, teachers are recomended to teach listening by using Digital Story Media.

\section{REFERENCES}

Abbas Pourhosein Gilakjani, S. M. (2011). The Relationship Between L2 Reading Comprehension and Schema Theory: A Matter of Text Familiarity. International Journal of Information and Educational Technology, 142-149.

Abidin, M. J. (2000). Test-taking Strategies, Schema Theory and Reading Comprehension Test Performance. International Journal of Humanities and Social Science, 237-243.

Anderson, J.R. 1982. Acquisition of Cognitive Skill. Psychological Review. 89: 369-406.

Brown, H. Douglas. 2004. Language Assessment: Principles and Classroom Practices. San Fransisco: Longman.

Brownell, Judi. 1996. Listening: Attitude, Principles, and Skills.Massachussets: Allyn and Bacon.

Cahyono, B.Y. \&Kusumaningrum, S.R. 2011.Practical Techniques for English Language Teaching.Malang: State University of Malang Press.

Chang, S. (2000). The Interaction Between Schemata and Subtitles. The Interaction Between Schemata and Subtitles , 1-19.

Chiu, T. K. (2012). Using Controllable Partial Sub1title and Interactive Features and Educational Videos. International Journal of Information and Educational Technology, 364-366.

Christensen, Larry B. 1977. Experimental Methodology. London: Allyn and Bacon Inc.
Crow L and Crow A. 1963. An Outline of General Psychology. New Jersey: Little Field, Adams and Co.

Dudeney, Gavin \&Hockly, Nicky. 2007. How to Teach English with Technology. Harlow: Longman.

Flowerdew, John. \& Miller, Lindsay. 2005. Second Language Listening: Theory and Practice. Cambridge: Cambridge Language Education.

Fraenkel, E Jack and Wallen, E. Norman. 1993. How to Design and Evaluate Research in Education. McGraw Hill International Edition.

Gall M D, G. J. (2007). Educational Research: An Introduction. New York: Pearson.

Grgurovic, M. (2011). Help Options and Multimedia Listening: Students Use of Subtitles and the Transcript. Language Learning and Technology , 45-66.

Herron, Carol A. \& Irene Seay. 1991. The Effect of Authentic Aural Texts on Student Listening Comprehension in the Foreign Languge Classroom: 487-95.

Long, Michael H. 1995. Input and Second Language Acquisition Theory. Newburry: Newburry House.

Mueller, G. 1980. Visual Contextual Cues and Listening Comprehension: An Experiment. Modern Languge Journal 64. 335-340.

Paula Winke, S. G. (2010). The Effects of Captioning Videos Used for Foreign Language Listening Activities. Language Learning and Technology, 65-86.

Richards, J.C. 2008. Teaching Listening and Speaking: From theory to Practice. Cambridge: Cambridge University Press.

Rost, Michael. 1991. Listening in Action. Norwich. Pentice Hall International.

Rost, Michael. 1994. Introducing Listening. London: Penguin Groups.

Roblyer, M.D. 2003. Integrating Educational Technology into Teaching-3rd Edition. New Jersey: Merril Prentice Hall.

Rubin, Joan. 2011. A Review of Second Language

Listening 
Comprehension

Research.

Wheaton: Hermitage Avenue.

Rubin, Joan. 1990. How Learner Strategies Can Inform Languge Teaching. Language Use, Language Teaching and the Curriculum. Hongkong: Institute of Languge in Education.

Salmi, M. A. (2011). Schemata (Background Knowledge) and Reading Comprehension for EFL Students. Research Journal Spesific Education , 696-708.

Schmidt-Rinehart, Barbara. 1992. The Effects of Topic Familiarity on the Listening Comprehension of University Students of Spanish. Ohio: Ohio State Univ.

Smith, N.M. \& Fitt, Stephen D. 1982. Active Listening at the Reference
Desk. American: American Library Association.

Teeler, Dede. \& Gray, Peta. 2000. How to Use the Internet in ELT. Harlow: Longman.

Tversky, B. \& Morrison, J.B. 2002. Animation: can it facilitate?. 57: 247-262.

Underwood, Mary. 1997. Teaching Listening. New York: Longman.

White, G. (2010). Listening. Oxford: Oxford University Press.

Wilson, J.J. 2009.How to Teach Listening. England: Longman.

Zanon, N. t. (2006). Using Subtitles to Enhance Foreign Language Learning. Porta Linguarium 6 , 4152. 